\title{
Investigating forty years of French politics through the prism of value change
}

\section{Céline Belot $^{1} \cdot$ Pierre Bréchon $^{1} \cdot$ Frédéric Gonthier $^{1}$}

Accepted: 27 April 2021 / Published online: 15 May 2021

(c) The Author(s), under exclusive licence to Springer Nature Limited 2021

\begin{abstract}
In this introduction, we advocate for an approach based on values when trying to make sense of shifts and changes that occurred in French politics during the last four decades. Values play a pivotal role in structuring political views and policy preferences. They influence citizens' attitudes and behaviors as well as reflect long-lasting political cultures and cleavages. After presenting the data collected within the European values studies, on which the six articles included in this issue build, we explain how these contributions highlight some major French political dynamics by scrutinizing key driving forces such as the individualization process, generational replacement or ideological consistency in economic and cultural beliefs, and by reassessing how attitudes toward democracy, religiosity and nationalism shape political attitudes. Challenging dominant narratives of value crisis, this issue sets up an agenda for future research on French politics through the lens of value change.
\end{abstract}

Keywords Values $\cdot$ Political changes $\cdot$ French politics $\cdot$ European values studies (EVS)

French politics is no longer what it used to be. Prior to the last presidential election, France had been governed since 1981 alternately by parties claiming to walk in De Gaulle's footsteps, successively, the RPR, UDF, UMR and $\mathrm{LR}^{1}$, and by the Socialist party and its allies. Conversely, the current president of France is the leader of a party, La République En Marche (LREM), which barely predates the 2017 French presidential election. Emmanuel Macron was a first-time runner when he came to office. In a similar vein, what was widely characterized as a political thunderstorm, that is, the 2002 qualification of the National Front candidate, Jean-Marie Le Pen,

\footnotetext{
${ }^{1}$ RPR: Rassemblement Pour la République; UDF: Union pour la Démocratie Française; UMP: Union pour un Mouvement Populaire; LR: Les Républicains.
}

Céline Belot

celine.belot@iepg.fr

1 CNRS, Sciences Po Grenoble, University of Grenoble, Pacte, France 
for the second round of the presidential election, became almost politics as usual when Marine Le Pen repeated her father's prowess in reaching the second round of a presidential election in 2017 (for an overview, see Faucher and Garcia 2018).

The same goes for voting behavior. During the 2017 runoff election, as many as 8.6 percent of the French electorate cast a blank or invalid vote, a record number for this type of election (Heinsohn 2018), with many voters admitting that they would have cast a blank vote if they had been included in official statistics (Courtin et al. 2018). In addition, sharply contrasting with the statement that the 'contentious French' are not contentious anymore, as trade unions find it increasingly harder to gather numbers at public demonstrations (Chabanet et al. 2018), social movements swept across the country on an unprecedented scale. The Yellow Vests were the objects of constant media attention and public agenda for seventy consecutive weeks, right until the Coronavirus lockdown of March 2020. Even though this form of protest is not unprecedented, it saw the emergence of a new kind of horizontal coordination in that the self-appointed leaders were discarded together with leaders of the French radical parties, whose anti-austerity and anti-migrant rhetoric failed to penetrate the movement (Guerra et al. 2019).

Up until now, a significant body of research has investigated shifts and changes in French politics from the perspective of party system and its new developments, such as the emerging conflict dimensions (see, e.g., Evans and Ivaldi 2017; Gougou and Persico 2017), the renewal of party platforms, strategies and campaign effects (see, e.g., Dolez et al. 2019; Perrineau 2017) or changes in the long run at the elite level and the underlying transformations of political recruitment channels (see, e.g., Boelaert et al. 2018). In this double special issue, we propose to shift the focus and address the dynamics of French politics through the lens of value systems as we believe values are substantial drivers of political changes (Inglehart 1977, 1990; Norris and Inglehart 2019).

\section{How values influence politics and how the European values study can help make sense of this influence}

Values are stable and enduring beliefs on what individuals consider important. They are conceptually different from, albeit related to, attitudes and behaviors. Attitudes express underlying value orientations in that individuals respond to situations based on the values they hold. Behaviors are shaped by values in that the latter manifest themselves in practical daily business. Values thus play a major role in structuring political orientations and policy preferences. They influence citizens' attitudes and behaviors, as well as reflect long-lasting political cultures and entrenched political cleavages.

Two complementary perspectives on political change can be derived from this rationale (van Deth and Scarbrough 1998). Values can first be viewed as mediating the linkage between the key political characteristics of a social structure and individuals' cognitive or behavioral orientations. A typical example is Inglehart's seminal claim that in advanced industrial societies, the combination of increasing economic prosperity, public safety and raising educational standards induced a shift in 
value priorities among younger cohorts. The resulting rise of postmaterialist values offered new political opportunities and challenged conventional forms of political participation, which gave way to new political cleavages (Flanagan 1982; Flanagan and Lee 2003; Inglehart 1984). One complementary explanation has to do with the impact of values on political change among various social groups. For instance, citizens who, while committed to democracy, express strong discontent with how politics is run, are found to be above average educated more often than not, with a gap between democratic aspirations and democratic satisfaction at its widest among the most educated (Norris 2011). This ambivalent loyalty toward political authorities derives in large part from postmaterialist values (Inglehart 1999; Klingemann 2014). As a result, dissatisfied democrats are critical of party politics while being immune from political radicality.

Drawing on prior research on values and their influence on politics, this special issue addresses how value changes have shaped the last forty years of French politics developments. Rather than using electoral studies, which usually contain a limited number of indicators tapping value orientations, it builds on the large amount of data collected by the European values studies (EVS) since the early 1980s. This social survey programme is profoundly marked by its original intellectual project. In line with Converse's (1964) conceptualization of belief systems as sets of functionally interdependent issue positions, the founding fathers of the EVS firmly believed that values form a consistent system. They advocated interpreting changes in one value domain in connection with changes in other domains (Arts and Halman 2004; Halman 2008). This claim explains in large part why the survey questionnaire investigates a wide array of topics, from family to religion, morality and social relations, work, the economy and politics.

The EVS provides unparalleled access to a wealth of material on how and why values have changed in Western and European societies (Bréchon and Gonthier 2017). Its initial goal, which has remained relevant to this day, was to devise a largescale comparative survey with a view to the sociopolitical attitudes and behaviors of European citizens in reaction to long-term changes induced by the decline and transformation of traditional religious, political or family ties. New items have been incorporated over the years to address emerging topics, such as immigration and environmental issues in the 1990s or European integration, democracy and gender equality in the 2000s. As for many cross-national surveys (Norris 2009), devizing a common questionnaire and harmonizing work routines to ensure quality and comparability proved challenging for the EVS from the very beginning. Increasing attention has notably been devoted to methodological requirements, with sampling procedures and the statistical representativeness of national samples significantly enhanced since the fourth survey round in 2008 (Luijkx et al. 2021).

The theoretical underpinnings of the EVS project also explain its frequency. The EVS aims at accounting for incremental sociopolitical and cultural changes rather than monitoring public opinion over a short period of time. It is well established that most of these changes occur through generational renewal (for the French case, see Tiberj 2017). Individual values are, indeed, stable predispositions throughout the life cycle in so much as they are acquired during pre-adult socialization through parents and peer groups (Jennings and Niemi 1968). A survey conducted every 9 or 
10 years - 1981, 1990, 1999, 2008 and 2017/2018 - is therefore consistent with this line of argument.

\section{Surveying and analyzing values in France}

In France, the latest EVS was carried out between March and August 2018. The dataset is made up of two samples. The main sample consists of 1,870 interviews achieved through a three-stage random sampling. A sample of 390 primary units (i.e., municipalities) was first selected, then a sample of secondary units (i.e., households) was drawn from the selected primary units, finally a sample of tertiary units was chosen (i.e., individuals aged 18 and over using the next-birthday method of respondent selection). In addition, 721 interviews were conducted with young people aged 18 to 29 using consolidated quotas in 200 randomly defined observation points. Quotas for age and sex (cross-tabulated), occupation and educational level were implemented. The latter criterion increases constraints on the fieldwork but ensures data reliability. With 1002 youngsters (721 in the subsample, 281 in the main sample), EVS data allow for a finer-grained analysis of French youths (Lardeux and Tiberj 2021). A weighting variable was computed based on region, size of town, sex and age, and level of education to adequately represent the French population.

In the light of previous survey rounds, the EVS data offer new insights into changing and unchanging aspects of French politics from a values' perspective. As findings reveal, the French turn out to be increasingly less conformist, while becoming more individualistic, altruistic and tolerant of different lifestyles, more strongly supportive of democratic principles, despite rampant disillusionment with party politics-i.e., with how politicians, parties and governments (fail to) address citizens' demands and concerns. Far from turning authoritarian, the French are merely voicing their demand for more public order, a necessary condition for the fulfillment of postmaterialist aspirations. This also explains widespread opposition to economic liberalism - in the European sense-and continued support of state intervention, in particular when it comes to issues of social justice. Moreover, religious practice has been fast declining with a majority of French currently identifying as non-believers or even avowed atheists. At the same time, they view secularity as a pillar of French politics (Bréchon et al. 2019).

This double special issue takes a step further by delving into French politics by means of six articles. The first batch compiles three cross-cutting articles whose primary focus is on core values and on how their structuring influences political attitudes and behaviors. As a starting point, Pierre Bréchon opens with the argument that the desire for autonomy in the conduct of one's life, which he terms 'individualization', is associated with stronger altruism, trust in others as well as with leftist orientations, egalitarian values and higher levels of political consciousness. Vincent Tiberj next addresses the impact of generational renewal on political participation. While France's Silent Generation was driven by a duty-based citizenship, Boomers are far more interested in, and critical of, politics. By contrast, Tiberj portrays their counterparts from Gen-X and Gen-Y as remote citizens, politically sophisticated and engaged, yet distant from party politics and more likely to abstain from 
voting. Chloé Alexandre, Frédéric Gonthier and Tristan Guerra also highlight the pivotal influence of political sophistication. They demonstrate that large swaths of the French population do not align their views on economic and cultural issues with the progressive conservative continuum prevalent among the political elites. Only among the minority of highly politically cognizant are we to find a consistent response to elite cues as a means of determining policy preferences and ideological identification. The three articles put national political trends in perspective with a broader international literature, thereby moderating the belief in French exceptionalism (for a similar argument see Elgie et al. 2016a, b).

The second bundle of articles comprises three pieces focusing on more specific political values, also stressing their impact on attitudes and behaviors. Sonja Zmerli examines how views on democracy bear an effect on political attitudes and participation. She finds, in particular, that the three chief common understandings of democracy, which she labels 'liberal', 'undemocratic' and 'social democratic', are differently affected by education and political ideology. In a similar fashion, Céline Belot disentangles varieties of nationalism among the French public and investigates their relationships with attitudes toward immigrants, solidarity and welfare. Her article challenges conventional wisdom by showing that those citizens who endorse inclusive and universalist views on national belonging are not necessarily more likely to favor a multicultural over an assimilative society. Finally, Claude Dargent stresses that Catholics, Muslims and the 'no religion' group continue to uphold distinct if not opposed party preferences in the current French society. These differences, he holds, result from diverging discrepancies in core cultural and moral beliefs, call for a more systemic account of the religious variables in public opinion studies. While offering meaningful insights into multiple dimensions of French political realm, these articles are far from exhausting the possibilities offered by the EVS. They should thus be considered as an invitation to delve more into the data to better understand value changes in less intensively analyzed topics such as gender, work, family or solidarity.

\section{Toward a new research agenda for values in French politics}

Put together, the six articles should however help readers weave through the complexity of value systems and their long-lasting impact on French politics. When scrutinizing the mainstream media discourse in France, the dominant narratives are undoubtedly those of a crisis of values (beginning with republican values ${ }^{2}$ ) and of increasing value-based conflicts. It is no surprise that values are strategically used by policy makers to frame policy issues instrumentally (i.e., by targeting groups with competing interests) as well as symbolically (i.e., by triggering emotions and moral concerns grounded in social and political identities). Yet, the articles presented in this special issue will hopefully balance out such alarmist narratives. First,

\footnotetext{
2 On the overwhelming influence of the Republican ideology in France and its specificities, see Meny (2017).
} 
they highlight that emancipative values (i.e., values emphasizing freedom of choice, social and gender equality) are increasingly supported since the 1980s, while traditional values (i.e., legitimizing external sources of authority such as religion, the nation and group norms) are losing ground in the long run. Most European countries follow a very similar dynamic of progress in emancipative values (Welzel 2013). Second, in contrast with the widespread narrative of a fragmentation of the French society, this special issue stresses that value cleavages are rather stable over time. Admittedly, socio-demographics such as age, income and education result in contrasting attitudes and behaviors. Yet, they do not exert a much greater influence today than in the recent past.

Reflecting on promising theoretical and empirical directions for the analysis of French politics through the lens of value systems, we see merit in more work addressing the issue of gender gaps. So far, scholars have evidenced that values are only marginally gendered in that gender differences are usually smaller than differences due to other socio-demographics (see, e.g., François and Magni Berton 2017). However, aside from this moderate direct influence, most of the mediating effects that gender is likely to exert on political attitudes and behaviors are yet to be illuminated. In particular, latest research on the interplay between gender, political participation and generational renewal points to the fact that gender gaps may well be steadier than expected and even larger among recent cohorts (see, e.g., Durovic 2017). By the same token, since gender differences in values are often greater between countries than within countries, the locus of attention in comparative studies could benefit from shifting from individual to aggregate analysis in order to better understand how the institutional and political context makes gender matter (Burns 2007).

Investigating how political competition influences shifts in value systems has not attracted much scholarly attention. The focus of the EVS project has long been on value change construed as primarily driven by a combination of economic (i.e., rise in economic development and educational levels) and cultural factors (i.e., postmaterialism and generational replacement). This conceptualization starts from the assumption of stable, established party systems, an assumption that is nowadays challenged in Europe. The weakening, in most West European countries, of parties previously considered as major governmental parties and the scattering of electoral forces has, in particular, given more leeway for voters to express the possible tensions between their economic and cultural preferences (Hillen and Steiner 2020). As they face a more volatile electorate and challenger parties using antiestablishment rhetoric to undermine their appeal, dominant parties are less able to maintain their control over the market for votes and political office. For future research it might be worth further exploring the linkage between value change and party system polarization. As it turns out, even though the economic dimension and the related class cleavage opposing market economy and state intervention remains pivotal in France, the cultural dimension is increasingly permeating through political competition, as dominant and challenger parties from both sides of the left-right opposition are showcasing issues such as immigration and relationship with Islam, thus directly appealing to voters' cultural values and identities. Prior research has found core values related to cultural issues more likely than economic concerns to 
affect policy preferences and party evaluations (Carmines and Stimson 1980; Mason 2018). Whether cultural values and identities grow increasingly party linked could, therefore, provide fresh insights into French politics.

\section{References}

Arts, W.A., and L. Halman, eds. 2004. European values at the turn of the millennium. Leiden, Boston: Brill.

Boelaert, J., S. Michon, and É. Ollion. 2018. Opening up politically but closing off socially. Elites and the French National Assembly in 2017. Revue française de science politique 68 (5): 777-802.

Bréchon, P., and F. Gonthier, eds. 2017. European values. Trends and divides over thirty years. Leiden, Boston: Brill Academic Publishing.

Bréchon, P., F. Gonthier, and S. Astor, eds. 2019. La France des valeurs: Quarante ans d'évolutions. Fontaine: Presses Universitaires de Grenoble.

Burns, N. 2007. Gender in the aggregate, gender in the individual, gender and political action. Politics \& Gender 3 (1): 104-124.

Carmines, E.G., and J.A. Stimson. 1980. The two faces of issue voting. American Political Science Review 74 (1): 78-91.

Chabanet, D., M. Cinalli, A. Muxel, S.M. Van Hauwaert, and T. Vedel. 2018. A post-contentious turning point for the contentious French? Crisis without protest in France. In Citizens and the crisis: Experiences, perceptions, and responses to the great recession in Europe, ed. M. Giugni and M.T. Grasso. Cham: Springer.

Converse, P.E. 1964. The nature of belief systems in mass publics. In Ideology and discontent, ed. D.E. Apter. New York, London: The Free Press.

Courtin, S., J.-F. Laslier, and I. Lebon. 2018. The 2017 French presidential election: Were voters happy with their first-round vote? French Politics 16 (4): 439-452.

Dolez, B., J. Fretel, and R. Lefebvre, eds. 2019. L'entreprise. Macron: Presses Universitaires de Grenoble.

Durovic, A. 2017. A longitudinal analysis of gendered patterns in political action in France: A generational story? French Politics 15 (4): 418-442.

Elgie, R., E. Grossman, and A.G. Mazur. 2016. A framework for a comparative politics of France. In The Oxford handbook of French Politics, ed. R. Elgie, E. Grossman, and A.G. Mazur. Oxford: Oxford University Press.

Elgie, R., E. Grossman, and A.G. Mazur. 2016. Toward a comparative politics of France. In The Oxford handbook of french Politics, ed. R. Elgie, E. Grossman, and A.G. Mazur. Oxford: Oxford University Press.

Evans, J., and G. Ivaldi. 2017. An atypical 'honeymoon' election? Contextual and strategic opportunities in the 2017 French legislative elections. French Politics 15 (3): 322-339.

Faucher, F., and N. Garcia. 2018. France: Political development and data for 2017. European Journal of Political Research Political Data Yearbook 57 (1): 98-107.

Flanagan, S.C. 1982. Changing values in advanced industrial societies Inglehart's silent revolution from the perspective of Japanese findings. Comparative Political Studies 14 (4): 403-444.

Flanagan, S.C., and A.-R. Lee. 2003. The new politics, culture wars, and the authoritarian-libertarian value change in advanced industrial democracies. Comparative Political Studies 36 (3): 235-270.

François, A., and R. Magni Berton. 2017. Are values gender-based? Gender gaps in Europe. In European values. Trends and divides over thirty years, ed. P. Bréchon and F. Gonthier. Boston: Brill Academic Publishing, Leiden.

Gougou, F., and S. Persico. 2017. A new party system in the making? The 2017 French presidential election. French Politics 15 (3): 303-321.

Guerra, T., C. Alexandre, and F. Gonthier. 2019. Populist Attitudes among the French Yellow Vests. Populism 3 (1): 1-12.

Halman, L. 2008. Changing values, persisting cultures and beliefs in 85 countries: Trends from the values surveys from 1981 to 2004. Leiden: Brill.

Heinsohn, T. 2018. Casting an invalid vote at the 2017 French presidential election. French Politics 16 (4): 383-399. 
Hillen, S., and N.D. Steiner. 2020. The consequences of supply gaps in two-dimensional policy spaces for voter turnout and political support: The case of economically left-wing and culturally right-wing citizens in Western Europe. European Journal of Political Research 59(2): 331-353.

Inglehart, R. 1977. The silent revolution: Changing values and political styles among western publics. Princeton, NJ: Princeton University Press.

Inglehart, R. 1984. The changing structure of political cleavages in Western Society. In Electoral change in advanced industrial democracies, ed. R.J. Dalton, S.C. Flanagan, and P.A. Beck. Princeton, NJ: Princeton University Press.

Inglehart, R. 1990. Culture shift in advanced industrial society. Princeton, NJ: Princeton University Press.

Inglehart, R. 1999. Postmodernization erodes respect for authority, but increases support for democracy. In Critical citizens. Global support for democratic governance, ed. P. Norris. Oxford New York: Oxford University Press.

Jennings, M.K., and R.G. Niemi. 1968. The transmission of political values from parent to child. The American Political Science Review 62 (1): 169.

Klingemann, H.-D. 2014. Dissatisfied democrats. In The civic culture transformed: From allegiant to assertive citizens, ed. C. Welzel and R.J. Dalton. Cambridge: Cambridge University Press.

Lardeux, L., and V. Tiberj. eds. 2021. Générations désenchantées? Jeunes et politique, La documentation française, Paris.

Luijkx, R., G.A. Jónsdóttir, T. Gummer, M. Ernst Stähli, M. Frederiksen, K. Ketola, et al. 2021. The European values study 2017: On the way to the future using mixed-modes. European Sociological Review 37(2): 330-346.

Mason, L. 2018. Uncivil agreement: How politics became our identity. Chicago, IL, London: University of Chicago Press.

Meny, Y. 2017. Republicanism: A transatlantic misunderstanding. In The Oxford handbook of French politics, ed. R. Elgie, E. Grossman, and A. Mazur. Oxford: OUP.

Norris, P. 2009. The globalization of comparative public opinion research. In The SAGE handbook of comparative politics, eds. T. Landman, N. Robinson. London: Sage.

Norris, P. 2011. Democratic deficit: Critical citizens revisited. New York: Cambridge University Press.

Norris, P., and R. Inglehart. 2019. Cultural backlash: Trump, brexit, and authoritarian populism. Cambridge, New York: Cambridge University Press.

Perrineau, P. ed. 2017. Le vote disruptif. Les élections présidentielle et législatives de 2017. Paris: Presses de Sciences Po.

Tiberj, V. 2017. Les citoyens qui viennent. Paris: PUF.

Van Deth, J.W., and E. Scarbrough, eds. 1998. The impact of values. Oxford; New York: Oxford University Press.

Welzel, C. 2013. Freedom rising. Human empowerment and the quest for emancipation. Cambridge Cambridgeshire. New York: Cambridge University Press.

Publisher's Note Springer Nature remains neutral with regard to jurisdictional claims in published maps and institutional affiliations. 